\title{
Design of Breakup Ice Control Structures
}

Andrew M. Tuthill and James $\mathrm{H}$. Lever

March 2006 


\title{
Design of Breakup Ice Control Structures
}

\author{
Andrew M. Tuthill and James H. Lever \\ Cold Regions Research and Engineering Laboratory \\ U.S. Army Engineer Research and Development Center \\ 72 Lyme Road \\ Hanover, New Hampshire 03755-1290
}

Final report

Approved for public release; distribution is unlimited.

$\begin{array}{ll}\text { Prepared for } & \text { U.S. Army Corps of Engineers } \\ & \text { Washington, DC 20314-1000 }\end{array}$ 


\section{ABSTRACT}

The primary purpose of a breakup ice control structure (ICS) is to retain a breakup ice run upstream of a traditional ice jam problem area and thereby mitigate ice-jam flooding. By controlling ice-jam location, breakup ICSs also can prevent ice-related scour associated with dam removals or contaminated sediment remediation projects. This report briefly describes basic ICS types, purposes, and advantages and disadvantages, and provides engineering design guidance for their use. The use of numerical and physical models to design these structures is illustrated through case studies. The report includes a checklist to help designers compile the necessary input data and to conduct the analyses needed to ensure successful designs. 


\section{CONTENTS}

Conversion factors, non-SI to SI units of measurement ……............................

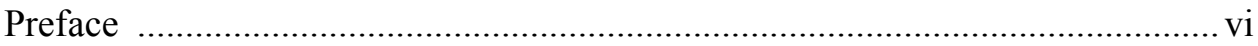

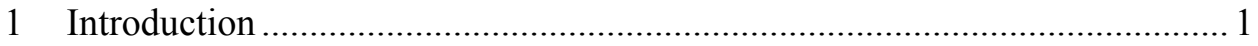

1.2. Dams and Weirs as Ice Control Structures ............................................. 2

1.3. Weir with Piers ICS.......................................................................... 2

1.4. Ice Booms for Breakup Ice Retention ................................................... 5

1.5. Upstream Water Level Rise Resulting from ICS ..................................... 5

1.6 ICS Reliability and Potential Failure Modes............................................. 5

1.7. Examples of Existing Breakup Ice Control Structures ............................ 6

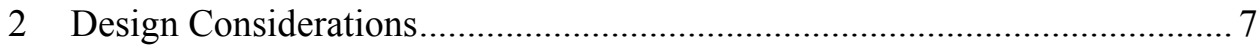

2.1. Characterization of Existing Ice Regime............................................... 7

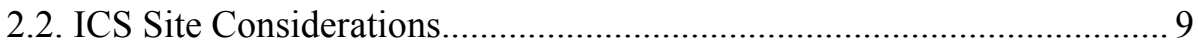

2.3. Modeling Existing Conditions and Candidate ICS Sites....................... 13

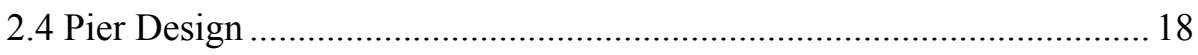

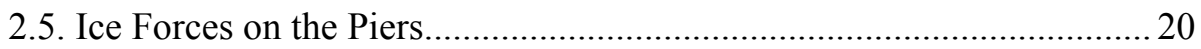

2.6. Bed and Bank Protection ........................................................................ 22

2.7. Extreme Events Failure Modes and Ice Jam Meltout............................ 22

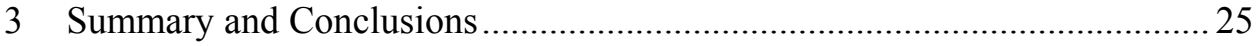

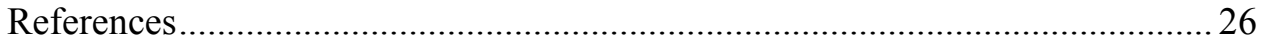

Appendix A. Breakup ICS Design Procedure ...................................................... 29

\section{ILLUSTRATIONS}

Figure 1. Concept drawing of the Hardwick, Vermont, ICS, which retains the breakup ice run behind boulders in the main channel while relief flow bypasses the structure via the floodplain ................................................ 3

Figure 2. Example of pier ICS with in-channel relief flow .................................. 4

Figure 3. Stage and discharge hydrographs for the Winooski River showing the formation and release of the 1992 ice jam at Montpelier, Vermont ....... 11

Figure 4. Ice-affected rating curve for the 1992 Montpelier ice jam .................. 12 
Figure 5. HEC-RAS simulations of existing-conditions ice jam compared to ice jam profiles resulting from upstream ice retention

Figure 6. Cazenovia Creek ICS under construction, September 2005 .................2 20

Figure 7. Measured moments on a pier, Cazenovia Creek physical model

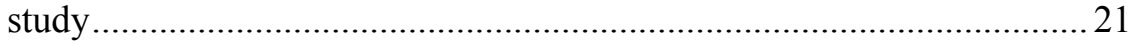

\section{TABLE}

Table 1. HEC-RAS-calculated ice-hydraulic parameters for a range of ICS designs 
CONVERSION FACTORS, NON-SI TO SI UNITS OF MEASUREMENT

Non-SI units of measurement used in this report can be converted to SI units as follows:

\begin{tabular}{|c|c|c|}
\hline Multiply & By & To obtain \\
\hline feet & 0.3048 & meters \\
\hline
\end{tabular}




\section{PREFACE}

This technical report was prepared by Andrew M. Tuthill, Research Hydraulic Engineer, Ice Engineering Research Group, RS/GIS and Water Resources Branch, and Dr. James H. Lever, Mechanical Engineer, Applied and Military Engineering Branch, U.S. Army Engineer Research and Development Center (ERDC), Cold Regions Research and Engineering Laboratory (CRREL), Hanover, New Hampshire.

Funding for this research was provided by the civil-works-funded Flood and Coastal Storm Damage Reduction Research Program, Ice-Affected Structures Work Unit.

This report was prepared under the general supervision of Timothy Pangburn, Chief, RS/GIS and Water Resources Branch, CRREL; Dr. Lance D. Hansen, Deputy Director, CRREL; and James L. Wuebben, Acting Director, CRREL.

The Commander and Executive Director of the Engineer Research and Development Center is Colonel James R. Rowan. The Director is Dr. James R. Houston. 


\title{
Design of Breakup Ice Control Structures
}

\author{
ANDREW M. TUTHILL AND JAMES H. LEVER
}

\section{$1 \quad$ INTRODUCTION}

This report provides engineering design guidance for breakup ice control structures (ICSs). Basic ICS types, their purposes, and advantages and disadvantages are briefly described. The overall approach, theory, and numerical and physical models used to design these structures are presented and illustrated through case studies such as the Cazenovia Creek ICS (Lever et al. 2000, 2001, 2003).

The primary purpose of a breakup ICS is to retain a breakup ice run upstream of a traditional ice jam problem area and thereby mitigate ice jam flooding. By significantly reducing the ice volume available to jam downstream, the ICS can prevent or reduce the extent of ice jam flooding. More recently, breakup ICSs are being considered to prevent ice-related scour associated with dam removals or contaminated sediment remediation projects. In the case of dam removal, an ICS would retain ice that once stopped behind the dam, preventing its transport downstream to jam and flood a populated area. For the purpose of contaminated sediment remediation, an ICS might be located upstream of a capping project to prevent ice jams in the project area and under-ice scour of the cap and underlying bed material (Alcoa 2004).

The full range of breakup ICS types is described in Chapter 3 of EM 1110-21612, Ice Engineering (USACE 2002), and details on selected structures can be found in "Breakup Ice Control Structures: Performance Review," ERDC/CRREL Technical Note TN-05-5 (Tuthill 2005). This report groups the structures into categories of dams and weirs, weirs with piers, and simple piers and boulders. We provide the most detailed design guidance for the latter group as we have the most experience with these structures. 


\subsection{Dams and Weirs as Ice Control Structures}

Although not their primary purpose, larger gated dams provide extremely reliable ice control as they typically retain the breakup ice run for all but the highest flows. Depending on the pool configuration and ice and flow conditions, overflow weirs may also retain or delay the breakup ice run, particularly where the pools contain significant frazil ice deposits that tend to lock the ice cover in place. Drawbacks of dams and weirs are capital expense and environmental disruption, as they trap sediment, impede fish passage, and, in some cases, interfere with recreational uses of the river.

\subsection{Weir with Piers ICS}

Weirs with piers spaced along the top are specifically designed to retain the breakup ice and allow water flow to pass beneath the ice accumulation and over the weir crest. To be successful, pool depth must be sufficient to create a mild upstream water-surface slope and relatively low water velocity within the breakup discharge range. Under these conditions, downstream forces on the ice due to water drag and gravity will be low enough that the ice accumulation arches between the piers without thickening excessively. A number of these structures have seen moderate success in southern Canada, the Riviere Ste. Anne ICS in St. Raymond, Quebec, being an example (Tuthill 1995, 2005). Drawbacks are cost, eventual sedimentation of the pool, and the barrier posed by the structure to fish migration and recreational uses of the river. Also, depending on pier spacing, discharge, and ice conditions, this type of structure may fail to retain the breakup ice run (Morse et al. in press).

\subsubsection{Pier ICS with floodplain relief flow}

This report focuses on simple bottom-founded pier structures, which are generally favored over the above-described structure types because of their lower cost and lower environmental impact. The ICSs designed for Hardwick, Vermont, and Cazenovia Creek, New York, are examples (Fig. 1; Lever et al. 1997, 2001). As the name implies, these structures consist of boulders or concrete piers spaced across the main river channel to retain ice arriving from upstream. By arresting the dynamic ice run, these structures trigger formation of an ice jam with a well-grounded toe region. Pier spacing is designed such that the ice pieces bridge between the piers despite average sizes much smaller than gap widths. At moderate discharge, most of the water passes through the grounded toe as porous flow. As discharge increases, flow can bypass the structure via an adjacent floodplain or engineered flow relief channel. A good design will provide 
sufficient floodplain or relief channel capacity to limit stage rise much beyond bankfull and avoid jam release over the blocks or piers.

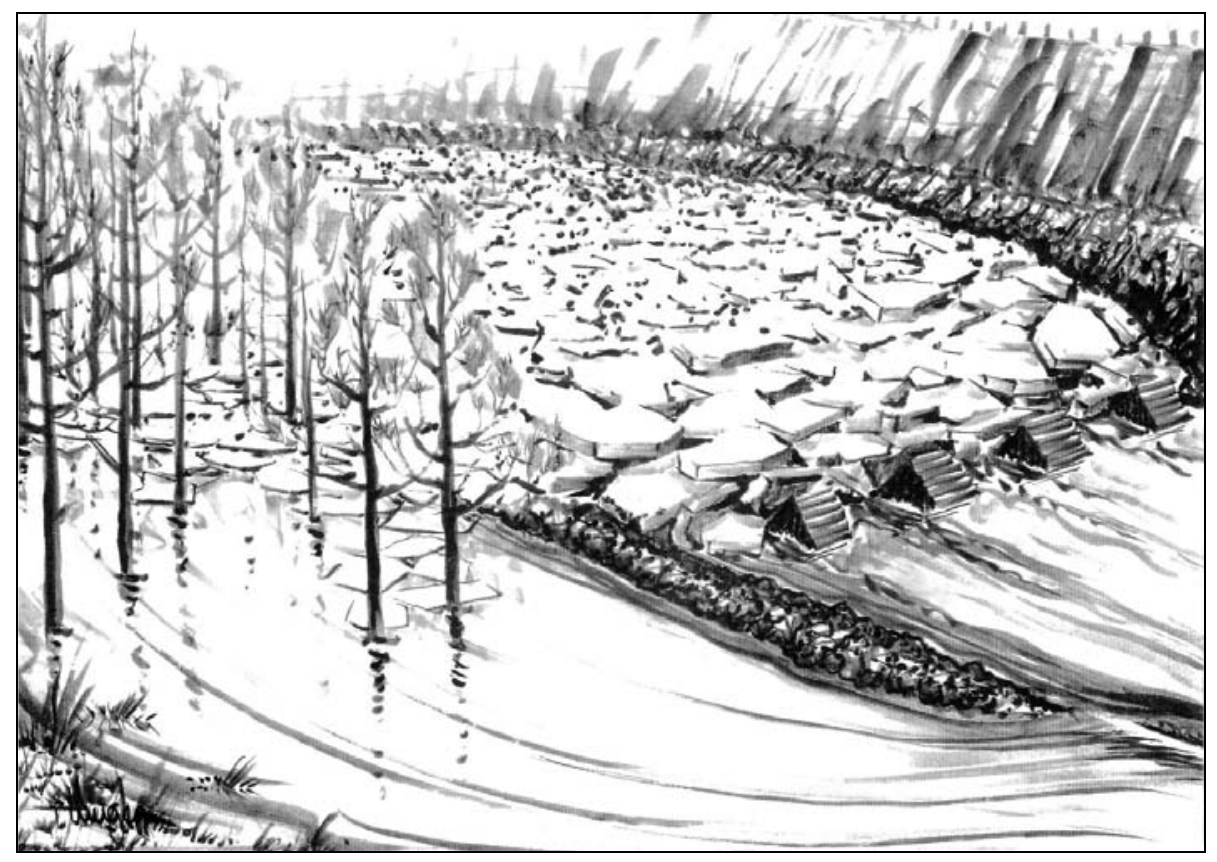

Figure 1. Concept drawing of the Hardwick, Vermont, ICS, which retains the breakup ice run behind boulders in the main channel while relief flow bypasses the structure via the floodplain.

In the absence of trees lining the bank edge, additional piers, posts, or boulders may be required to prevent ice from leaving the main channel and clogging the flow relief channel. Some designs include a rock berm along the floodplain margin to prevent flow from re-entering the main channel in the vicinity of the piers and eroding the jam. The primary jam-failure mode is ice blowout between two or more of the piers, or in the case of very high water discharge, ice floes may be carried over the top of the piers. Because of the high water velocities in and around the structure, scour protection is an important ICS design consideration, often representing a major portion of the project cost.

\subsubsection{Pier ICS without floodplain relief flow}

A limitation of pier ICS designs with overbank flow relief is that many sections of river lack adjacent floodplains for bypassing flow around the jam at the piers. If the cross-sectional flow area is large enough, and the breakup discharge sufficiently moderate, it may be possible to pass the water flow beneath or 
through a stable ice accumulation retained within the banks of the main channel. The discharge at which jam failure will occur will be less than when flow bypass is possible, but this value might nevertheless provide a useful level of flood mitigation.

\subsubsection{Pier ICS with in-channel relief flow}

A new concept termed "in-channel relief flow" uses a longitudinal row of piers aligned parallel to one bank. As a minimum, these longitudinal piers increase the width of the jam toe. Depending on hydraulic conditions, they may also provide a relief path around the grounded portion that forms behind the piers that are perpendicular to the main flow. Recent numerical simulations predict that in-channel relief flow will sufficiently reduce under-ice water velocities to prevent ice jam blowout between the piers of an ICS (Tuthill et al. 2005a). Although untested in prototype, the concept is noted here because it increases the flow area within the constraints of the main channel and might provide a viable means of retaining ice at sites without floodplains for bypass flow. Figure 2 shows a schematic plan of a pier ICS with in-channel relief flow.

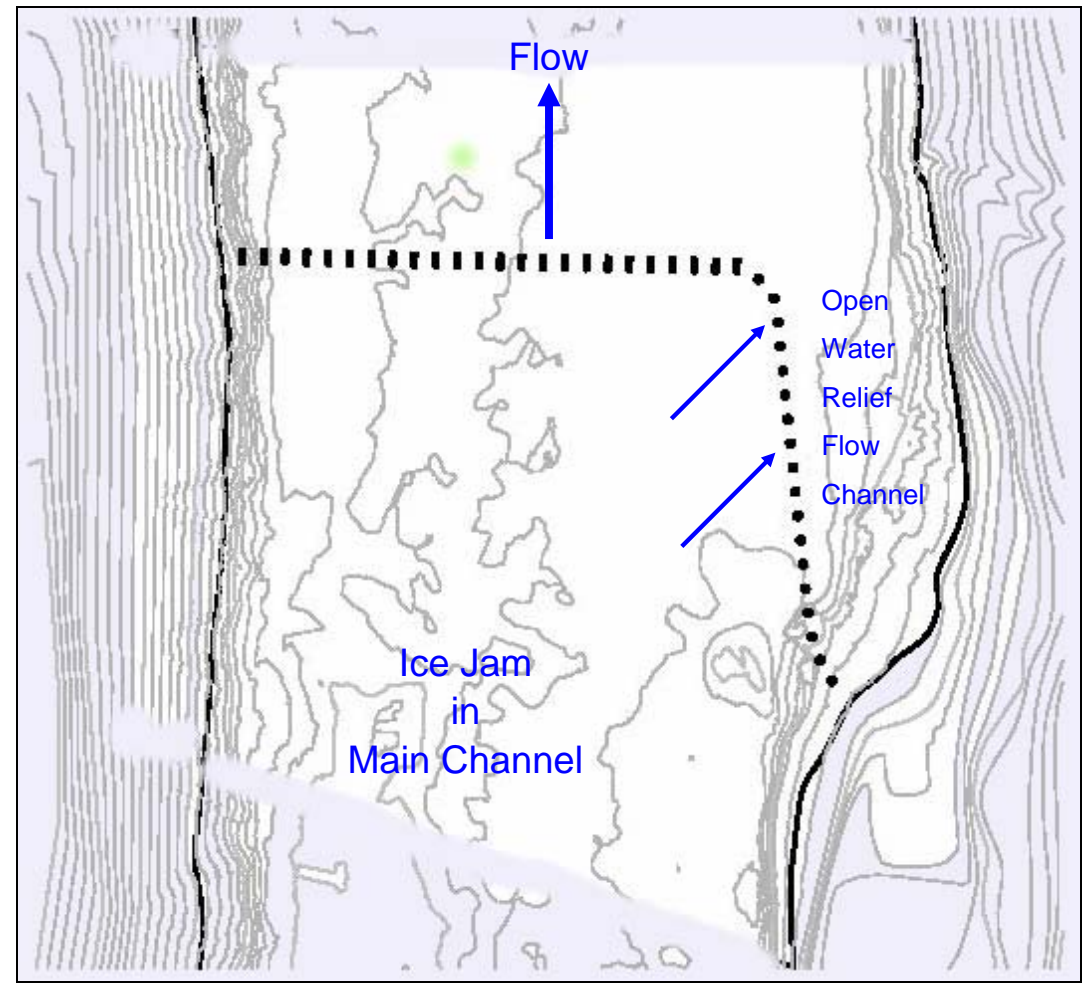

Figure 2. Example of pier ICS with in-channel relief flow. 


\subsection{Ice Booms for Breakup Ice Retention}

Another new concept developed by Fleet Technology* uses floating booms to delay release of ice cover breakup and retain the breakup ice run. Although floating booms have been used for decades to capture frazil and brash ice under quiescent hydraulic conditions typical of the ice formation period (water velocity $\leq \sim 2.3 \mathrm{ft} / \mathrm{s}$, Froude Number $\leq \sim 0.1$ ), until recently booms were not considered for breakup ice control. Fleet Technology has demonstrated the feasibility of steel pipe booms placed in series to retain breakup ice at water velocities above $3 \mathrm{ft} / \mathrm{s}$ on Riviere des Prairies in Quebec (Abdelnour 2003). Advantages of booms over bottom-founded piers are the lower capital cost and minimal environmental disruption. Disadvantages are the annual time and cost of installing and removing the boom, and the lower level of confidence in booms for breakup ice retention compared to pier structures.

\subsection{Upstream Water Level Rise Resulting from ICS}

Regardless of structure type, upstream water level rise is a critical ICS design issue (Lever and Daly 2003). Because an ICS will cause a jam where none may have occurred before, upstream land may experience higher water levels with greater frequency. A careful analysis of upstream effects is therefore an important part of breakup ICS design as it affects the process of land acquisition and obtaining flood easements. Depending on the site, land issues may have a large impact on project cost and the public acceptance of the project.

\subsection{ICS Reliability and Potential Failure Modes}

Reliability is a major consideration in ICS design. A common scenario for both the natural and ICS cases is for ice breakup and jams to occur on the rising limb of the hydrograph. Following jam formation, as discharge continues to increase, so will the downstream forces and hydrostatic head acting on the ice accumulation behind the piers. Possible outcomes range from gradual melting in place or metered release through one or two of the pier gaps, to a massive release between multiple piers. Great care must be taken to avoid this third type of scenario, as the ICS may pose a greater public hazard than the one it is trying to prevent. In light of this, a careful and conservative design approach is advisable.

\footnotetext{
${ }^{*}$ Fleet Technology LLC (http://www.fleetech.com/capabilities_coldregions booms.html)
} 


\subsection{Examples of Existing Breakup Ice Control Structures}

Examples of successful breakup ice retention structures including dams, weirs, weirs-with-piers, and pier structures are described in "Breakup Ice Control Structures: Performance Review," ERDC/CRREL Technical Note TN-05-5 (Tuthill 2005). 


\section{DESIGN CONSIDERATIONS}

\subsection{Characterization of Existing Ice Regime}

An initial step in breakup ICS design is to characterize the existing ice regime and the ice jam problem. The ice regime is defined here as the overall process of ice cover formation, maximum ice extent and thickness, the sequence of the ice breakup, and the degree of variability from year to year. An understanding of the frequency and severity of past ice jam events is also critical in ICS design. Based on knowledge of the ice regime and the history of past ice events, an estimated "worst-case" ice event can then be developed for use in ICS design. Tuthill (1996) and Shen et al. (2005) describe methods for calculating probabilities of occurrence of historic ice events.

\subsubsection{Historical research}

Background ice jam research typically begins with a review of historic ice events. A good source is the CRREL ice jam database* (IJDB), which now contains information on more than 14,200 ice events. Historical ice jam information sources also include local newspapers, libraries, town records, and discussions with locals familiar with the river. Concurrent review of hydrometeorological records can focus the historical research by identifying periods needing more detailed review.

\subsubsection{Important data on ice events}

Important data include event dates, peak ice jam stages, damages, and the discharge hydrographs surrounding the ice events. Air temperature data allow estimates of pre-breakup ice thickness. ${ }^{\dagger}$ Knowing whether the melting period leading up to ice release was gradual or rapid is important, since a quick thaw and breakup typically produces thicker, stronger ice pieces that are more likely to form severe jams. Precipitation data are also important since rainfall is often a key ingredient in dynamic breakups that result in severe ice jams. Data on the snowpack and degree of frost in the ground are important as they affect the runoff response and the form of the breakup hydrograph. For ungaged basins, hydrograph comparison techniques or hydrologic models that incorporate snowmelt are useful in reconstructing hydrographs surrounding historic breakup ice jam events.

\footnotetext{
* http://www.crrel.usace.army.mil/ierd/ijdb/

${ }^{\dagger}$ EM Ice Engineering describes a method to calculate ice thickness from air accumulated freezing degree day data.
} 


\subsubsection{River inspection}

A river inspection may help validate the findings of the historic ice jam research. Often riverbanks will show evidence of past ice events in the form of ice-scarred trees. The spatial extent, height, and density of the tree scars indicate where ice jams have occurred, the maximum ice-affected water levels, and, to some extent, the ice jam frequency. By sawing a tree with multiple scarring and healing cycles and counting annual growth rings, one can actually date historic ice events. Tuthill et al. (2005b) provide a more detailed analysis of ice jam tree scars as an indicator of past ice jam frequency and severity.

\subsubsection{Ice-affected rating curve}

Based on historic event and hydrometeorological data, an ice-affected rating curve can be constructed for the study reach. This stage discharge relationship is useful in ICS design since it provides an estimate of the water level rise necessary to break up and transport the ice cover, the discharge range within which ice jams typically exist, and the approximate discharge at which an ice jam will release. Lacking a nearby stream gage, a simple hydraulic model such as HECRAS with the ice option can be used to construct the ice-affected rating curve. Figure 3 shows the stage and discharge hydrographs for the Winooski River at the Montpelier, Vermont, gage for an extreme ice jam that occurred in 1992. Figure 4 shows ice-affected rating curve for an upstream location, constructed using the HEC-RAS model.

\subsubsection{Ice jam volume, ice supply and losses, and sequence of breakup}

Other important design considerations relate to pre- and post-breakup ice volumes, and the sequence of the ice breakup. This requires a good estimate of the maximum probable ice supply and knowledge of where the upstream ice originates, as well as the sequence of breakup. For example, on some rivers, breakup may progress very rapidly down a long reach of river to form a single large jam at the downstream end. In this case, the portion of the total ice supply that melts or deposits along the banks may be relatively small. At the other extreme, breakup may occur as a progressing series of jams and releases with significant enroute ice losses due to melting and ice deposition along the floodplains. Enroute ice losses due to melting and deposition vary greatly from nearly zero to as high as 90 percent, and the loss fraction generally increases with channel distance and ice travel time. On many rivers, features such as dams, pools, bridges, tight bends, islands, or constrictions may cause upstream ice jams that limit the ice volume that reaches a downstream jam site or ICS. When relating ice jam volume and the pre-breakup ice supply, it is important to consider ice jam 
porosity, which is on the order of 40-50 percent. Additional information and methods for calculating enroute ice losses can be found in White (1999) and Lever et al. (2003).

With an estimate of the probable maximum pre-breakup ice thickness, one can construct a cumulative ice volume curve vs. channel distance for the river as shown in Figure 5. HEC-RAS has a cumulative ice volume output option, which greatly simplifies this task, but lacking surveyed channel geometry, one can construct the ice volume curve based on river widths and reach lengths scaled from USGS mapping. Combined with a knowledge of the probable source reaches and the enroute ice losses, this ice volume curve is useful in subsequent simulations of ICS site alternatives, since one can estimate the portion of the ice volume intercepted by the ICS and the reduced ice volume that reaches the traditional jam location downstream.

Because a well-designed pier ICS can hold ice to high discharge, ice loss through melting and minor washouts will significantly reduce retained ice volume during extreme events (Lever and Daly 2003). These processes should be accounted for to predict realistic water levels upstream of the ICS to delineate flowage easements. Water temperature measurements during breakup events are rare, but water flowing at only $33^{\circ} \mathrm{F}$ can cause an ice volumetric melt rate of about $1 \%$ of water discharge. Some gaging stations record water temperature. The water temperature immediately after ice clears the gage should equal the temperature of water that was arriving at the upstream end of the ice jam.

\subsection{ICS Ice-Holding Capacity}

A series of ice-retaining piers across a river channel can form an extremely effective breakup ICS. The Hardwick ICS has 14-ft gaps between sloped granite blocks that protrude $1 \mathrm{ft}$ above the adjacent floodplain elevation (Lever et al. 1997). It can hold a breakup ice jam for hours to days, depending on the ice thickness (Lever and Gooch 2005, in review). The Cazenovia Creek ICS has 12-ft gaps between vertical cylindrical piers that protrude $3 \mathrm{ft}$ above the adjacent floodplain elevation. Based on model tests, it can retain ice at discharges approaching the 100-year flow, depending on ice thickness, although minor washouts of ice through the gaps begin to become significant at about half of this discharge (Lever et al. 2001, 2003).

At present, model tests are the most reliable way to quantify the ice-holding capacity of a given ICS design. The appropriate measures are holding time or release discharge as a function of ice thickness (Lever and Gooch 2005, in review). Once formed, the jam will collapse onto the ICS as discharge increases, typically forming a grounded toe region and raising water levels to ensure 
stability of the floating upstream jam. The key is to ensure adequate flow relief to prevent over-topping of the piers or catastrophic ice washout through one or multiple gaps. Porous flow through the grounded toe can be sufficient to allow half or more of the total discharge to pass through the jam at peak flow (Lever et al. 1997, 2001, in review). Floodplain conveyance serves to bypass the remaining flow and limit stage rise, and hence forces, at the ICS.

Lever and Gooch (in review) found that model and field data for ice-holding capacity of the Hardwick ICS were consistent: the ICS will hold ice thicker than about $7 \%$ of the gap width ( $\sim 1$-ft average thickness) throughout a breakup event. Unfortunately, general guidance relating pier spacing to ice-holding capacity does not exist, hence the preference for model tests to establish this function for a given ICS design.

\subsection{ICS Site Considerations}

Important factors in ICS site selection include hydraulic conditions, channel morphology, the existing ice regime, and the potential effects on upstream lands. As mentioned in the above discussion of ice volume, the ICS must be located close enough to the problem area that it retains sufficient ice to prevent downstream ice jam flooding or under-ice scour, depending on the purpose of the structure. Again, this requires a good estimate of the maximum probable ice supply and knowledge of where the upstream ice originates, as well as the sequence of breakup.

For the expected breakup discharge range, hydraulic conditions near an ICS must be sufficiently mild that ice does not overtop the piers. As mentioned, a number of successful breakup ICS designs take advantage of an adjacent floodplain area to bypass water flow around the jam that forms in the main channel. This relief valve mechanism limits upstream stage rise and prevents excessive water velocity in the ice jam toe region.

Finally, it is important to consider the ice conditions directly upstream of the structure at the time of breakup. Ideally, ICS reach will be sufficiently flat that the breakup ice run from upstream will impact semi-intact sheet ice upstream of the piers rather than the piers themselves. This will ensure that large rather than small ice floes pile against the piers, reducing the tendency for jam failure and ice blowout between the piers. 


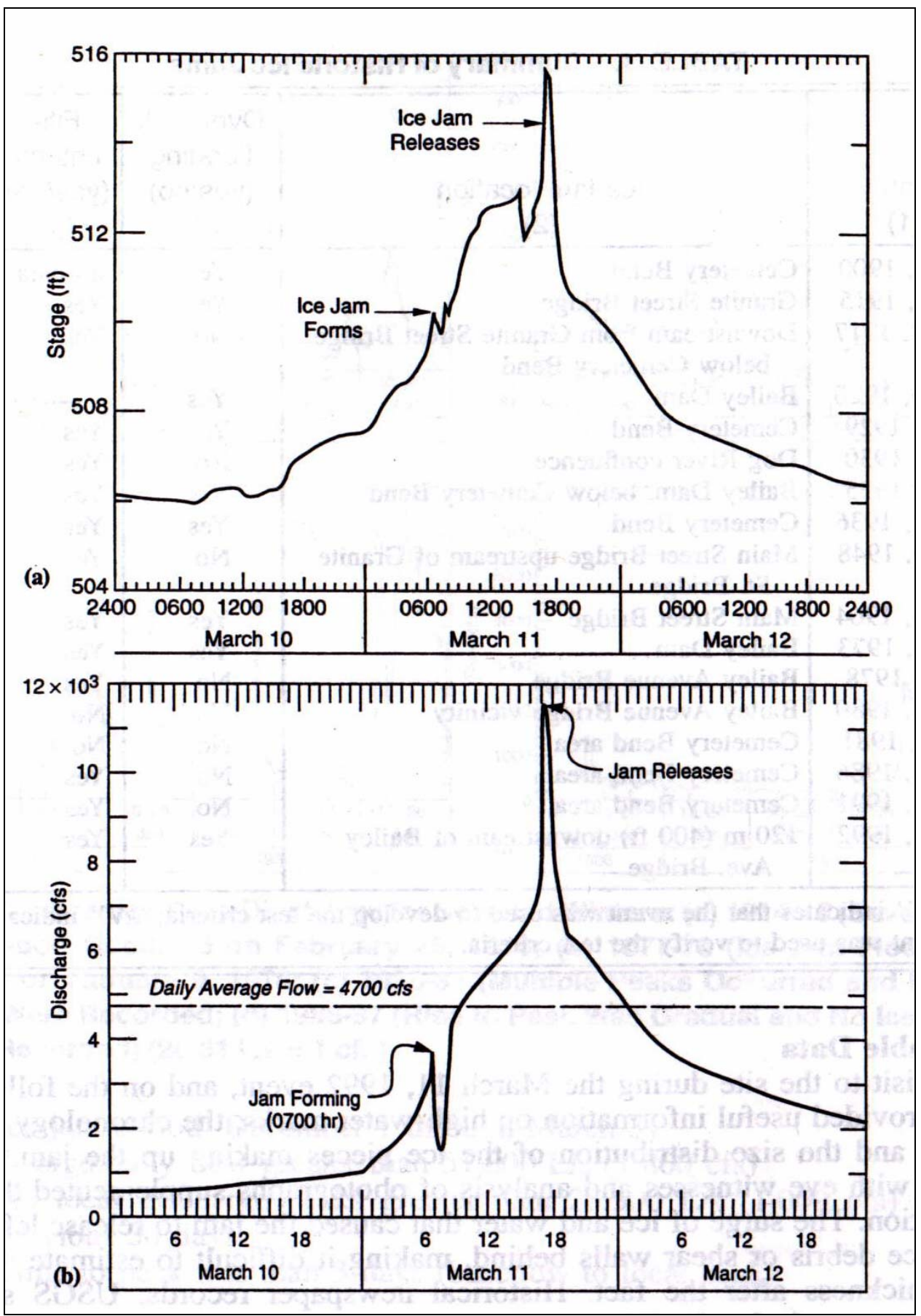

Figure 3. Stage and discharge hydrographs for the Winooski River showing the formation and release of the 1992 ice jam at Montpelier, Vermont. 


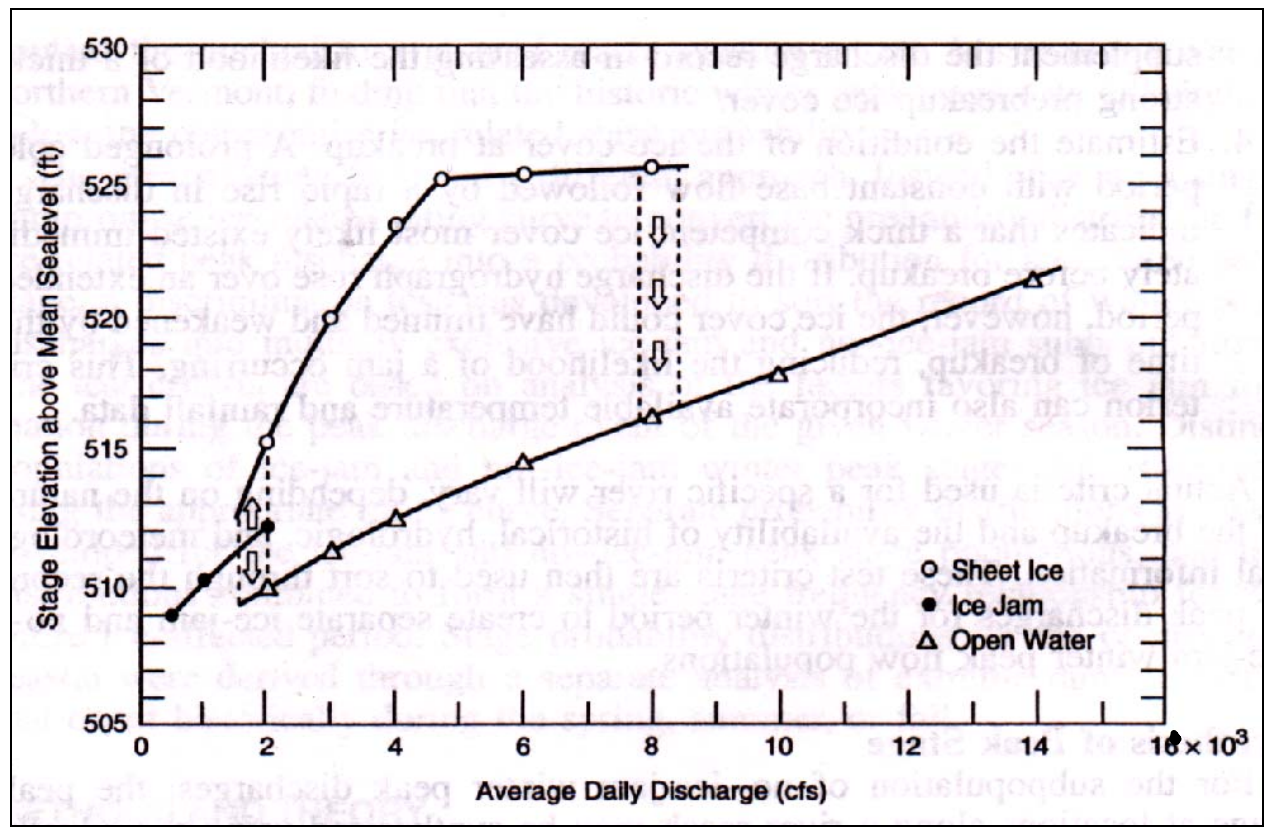

Figure 4. Ice-affected rating curve for the 1992 Montpelier ice jam.

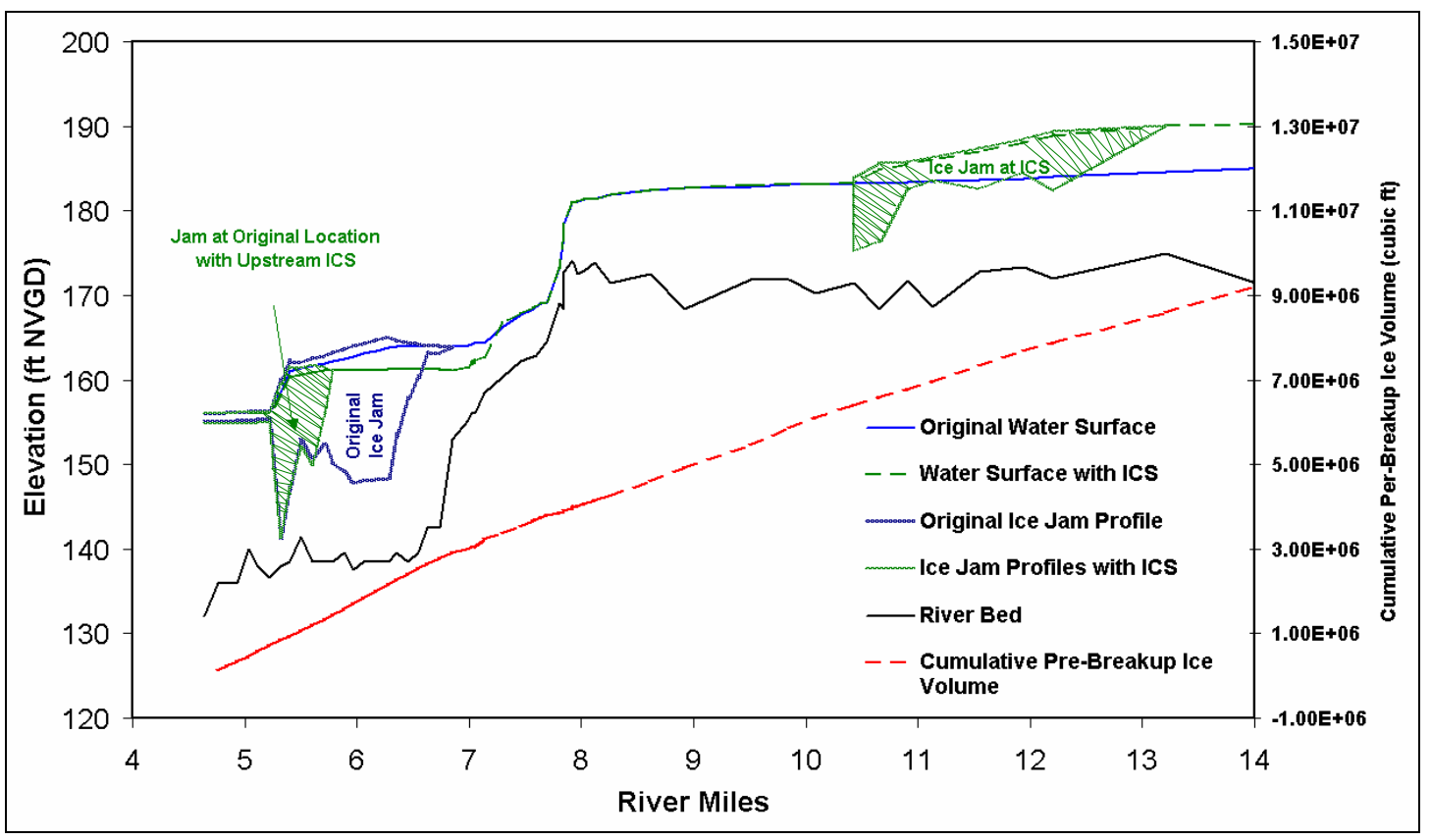

Figure 5. HEC-RAS simulations of existing-conditions ice jam compared to ice jam profiles resulting from upstream ice retention. The cumulative pre-breakup ice volume is also shown. 


\subsection{Modeling Existing Conditions and Candidate ICS Sites}

Modeling approaches range from simple one-dimensional flow equations with an ice cover of equilibrium thickness (USACE 2002) to sophisticated numerical and physical ice-hydraulic models. Depending on the specific ICS application and needs, these calculations and models provide estimates of ice accumulation stability, ice jam volume, and upstream effects, both at the candidate ICS site and in the original ice jam location. Numerical ice-hydraulic models useful in ICS design range from the widely used, steady-state, onedimensional HEC-RAS model (U.S. Army 2000) to more sophisticated models such as DynaRICE (Shen et al. 2000) and the CRREL DEM (Daly and Hopkins 2001). The latter two multi-dimensional numerical models with unsteady hydraulics and ice dynamics are excellent ICS design tools, but require considerable experience to use. Physical ice-hydraulic models provide the greatest design confidence, especially where three-dimensional ice-structure interaction and ice erosion processes are involved. The physical model studies are usually more costly and require more time to accomplish.

Choice of modeling approach will depend on the scale of the project, the reliability required and unusual aspects of the site, as well as the project schedule and funding. For example, it may not make sense to spend a significant portion of the total available funds on a physical model study of a cylindrical-pier ICS design at a site where hydraulic conditions are known to be relatively mild. On the other hand, if the consequences of ice jam failure at the structure are high, or the design is unconventional in nature, then the cost of more sophisticated numerical modeling or a physical model study is probably a good investment.

\subsubsection{Model calibration to existing-conditions ice event}

The first task is to simulate the existing-conditions historical ice jam event based on the information collected in Section 2.1. Important calibration parameters include ice jam location and extent, maximum ice jam water levels and, if available, ice jam thickness. Ice jam extent is usually known, particularly the location of the downstream end of the jam, or ice jam toe. Ice jam stage can be estimated from maximum observed flood levels, or reconstructed after the fact from photos or anecdotal evidence. Ice jam thickness is more difficult to determine but can sometimes be estimated by the height of ice rubble in shear walls left behind after the jam releases.

Numerical or physical modeling of an existing-conditions ice jam can then be compared to simulated ICS site alternatives as shown in Figure 5. In many cases HEC-RAS, with a few assumptions, is adequate to assess the benefits (via reduced downstream ice volume) of a given ICS site. Advantages of HEC-RAS 
are its simplicity and the fact that many hydraulic engineers are familiar with its use. For these reasons ice jam modeling using HEC-RAS is discussed in the following paragraphs.

The HEC-RAS ice jam routine treats the ice accumulation as granular material using Mohr-Coulomb theory to calculate internal stresses. Downstreamacting forces on the floating ice accumulation of water drag and gravity are transferred laterally through the granular ice material to be resisted by bank friction. In the simplest sense, the ice accumulation reacts to increased downstream forces by thickening. The model does not account for unsteady effects such as water or ice acceleration, nor can it simulate ice jam grounding or porous flow through the ice jam. Also, the HEC-RAS user must specify the locations of the downstream and upstream ends of the jam. Still, it is possible to simulate certain ice jam conditions with fair accuracy, particularly in the jam mid-section where ice thickness and the downstream-acting forces are fairly uniform.

Although ice jams commonly form under conditions of unsteady flow, the user must select a constant discharge as an input to the HEC-RAS model. One approach is to use the daily average discharge, which, in many cases, is the only data point available. If more detailed hydrograph data exist, one can select a discharge to represent the period when the ice jam profile is near its maximum but below the point of release. Another approach is to simulate the jam at several discharges within the known ice jamming range. The ice-affected rating curve described in Section 2.1 is useful in the selection of ice jam discharges to use in the HEC-RAS simulations.

Calibration parameters used in the HEC-RAS ice routine include Manning's roughness for ice $n_{i}$, ice erosion velocity $v_{\text {eros }}$, ice jam porosity $e$, and ice accumulation internal strength, expressed as the Mohr-Coulomb $\Phi$ angle. Typically, ice jam porosity is in the $0.4-0.5$ range and $\Phi$ is usually held constant at about $45^{\circ}$.

Ice jam thickness is most sensitive to $n_{i}$ and $v_{\text {eros }}$. Typical ranges for $n_{i}$ for breakup ice jams are in the 0.03-0.1 range and tend to increase with ice jam thickness. HEC-RAS contains an option that automatically relates ice roughness to ice thickness (U.S. Army 2000), but more realistic and stable results can usually be obtained by using fixed ice roughness values. A dilemma exists in that a thicker-smoother ice accumulation can produce the same calculated water surface profile as a thinner-rougher ice jam. For this reason it is important to use reasonable values of ice roughness and check that the resulting HEC-RAScalculated ice jam thickness also makes sense, based on field observation and experience.

The greatest modeling difficulties occur in the ice jam toe region where natural jams tend to be much thicker than the HEC-RAS-simulated ice jams. This 
is because the downstream acting forces on the real jam are resisted not only by the bank friction, but by channel obstructions or ice grounding to the bed. Also, when the real jam forms, the momentum loss produces greater ice thicknesses than those predicted by the static force balance used in HEC-RAS. One effective way to artificially thicken the toe of the HEC-RAS-simulated jam is to increase the ice erosion velocity for the first one or two cross sections. A v veros value of 10 $\mathrm{ft} / \mathrm{s}$ serves this purpose, but some trial and error is usually needed to match the observed ice jam profile. This allows a thicker ice accumulation, since flow continuity can be maintained with the high-velocity water passing through a smaller cross-sectional area beneath the jam toe. Another approach is to fix ice jam thickness in the toe region instead of calculating ice thickness based on the force balance. Finally, one can artificially thicken the jam toe by assigning very high roughness values to the lowermost cross sections.

\subsubsection{Simulation of candidate ICS locations}

The simulation of the existing-conditions ice jam serves as a baseline for comparison to simulated jams at candidate upstream ICS sites and a jam at the original site with the residual ice supply, as shown in Figure 5. For consistency, one should begin with the same total ice volume and ice jam parameters in the simulation of alternative ICS sites as used in the existing-conditions simulations. Depending on ICS site location, the cumulative pre-breakup ice volume curve described in Section 2.1.5 is used to estimate the portions of the total ice volume in the ice accumulation at the ICS and at the original ice jam location. However, the ICS is normally intended to hold a stable jam at much higher discharge than is possible for a natural ice jam. Thus, estimates of ice melting and washout rates are needed to produce realistic estimates of ICS jam volume at high discharge (Lever and Daly 2003).

An ideal ICS site will lie on a relatively flat section of river with an adjacent active floodplain for bypass flow. Active floodplain is defined as overbank area that is inundated fairly frequently. Locating the ICS as close as possible to the downstream ice jam problem area will provide the greatest ice jam flood control benefit as it will retain the greatest portion of the total ice supply.

Important questions to be answered by the calculations are 1) Is the stage rise at the ICS at peak discharge within the ice-holding capacity of the ICS? 2) Is the floodplain adequate to convey relief flow around the jam in the main channel? 3) Will the ICS retain a large-enough ice volume to mitigate the downstream ice jam problem? and 4) What are the upstream consequences of holding a jam at this site? 
The stability of a HEC-RAS simulated ice accumulation can be assessed based on the form of the ice jam thickness profile and the calculated under-ice velocity. Using reasonable ice parameters (Section 2.4.1), indicators of a stable ice accumulation are a relatively uniform ice thickness profile in the jam midsection and water velocities of about $4 \mathrm{ft} / \mathrm{s}$ or lower beneath the ice jam midsection. Calculated under-ice velocities of $5 \mathrm{ft} / \mathrm{s}$ or greater in the jam midsection suggest that the ice accumulation is probably unstable, either because the channel is too steep or the unit discharge ${ }^{*}$ too high. The result will be that the downstreamacting forces of water drag and ice accumulation weight will compress and thicken the jam toward the downstream end possibly to the point of grounding. At this point, water flow must pass either through the pore space of the jam, or as relief flow around the jam. DynaRICE and the CRREL DEM are capable of modeling the ice thickening, ice erosion, grounding, and porous flow while HECRAS cannot simulate these processes. Beltaos (1993) describes a method for calculating the portion of porous flow through the ice jam as a function of hydraulic gradient, wetted cross-sectional jam area, and a seepage coefficient. A conservative approach to modeling a grounded jam with HEC-RAS is to simply block off the main channel and assume all water bypasses the jam via the floodplain, if one exists. This also provides a means of evaluating the conveyance capacity of the overbank area, another important design parameter. Inclusion of through-jam porous flow will then increase the discharge at which the ICS can hold ice.

Table 1 lists HEC-RAS-calculated ice-hydraulic parameters for a range of ICS designs, giving an idea of the ice accumulation stability range.

\footnotetext{
${ }^{*}$ Discharge per unit width of river, expressed as $\mathrm{cfs} / \mathrm{ft}$ or $\mathrm{ft}^{2} / \mathrm{s}$.
} 


\begin{tabular}{|c|c|c|c|c|c|c|c|c|c|c|c|c|}
\hline \multirow[b]{2}{*}{ ICS } & \multirow[b]{2}{*}{$\begin{array}{c}\text { Breakup Q } \\
\text { (cfs) }\end{array}$} & \multirow{2}{*}{$\begin{array}{l}\text { Bankfull } \\
\text { width } \\
\text { (ft) }\end{array}$} & \multirow{2}{*}{$\begin{array}{l}\text { Bankfull } \\
\text { depth } \\
\text { (ft) }\end{array}$} & \multirow[b]{2}{*}{$\begin{array}{l}\text { Unit Q } \\
\text { (cfs/ft) }\end{array}$} & \multirow[b]{2}{*}{$\begin{array}{c}\text { Average } \\
\text { bed slope }\end{array}$} & \multirow{2}{*}{$\begin{array}{l}\text { Percent } \\
\text { overbank } \\
\text { flow }\end{array}$} & \multicolumn{2}{|c|}{$\begin{array}{c}\text { Ice } \\
\text { thickness } \\
\text { (ft) }\end{array}$} & \multicolumn{2}{|c|}{$\begin{array}{l}\text { Under-ice } \\
\text { depth } \\
\text { (ft) }\end{array}$} & \multicolumn{2}{|c|}{$\begin{array}{l}\text { Under-ice } \\
\text { velocity } \\
\text { (ft/s) }\end{array}$} \\
\hline & & & & & & & Toe & $\begin{array}{l}\text { Mid } \\
\text { jam }\end{array}$ & Toe & $\begin{array}{l}\text { Mid } \\
\text { jam }\end{array}$ & Toe & $\begin{array}{l}\text { Mid } \\
\text { jam }\end{array}$ \\
\hline Cazenovia Creek $^{\mathrm{E}}$ & $\begin{array}{c}6,000 \\
12,000\end{array}$ & 150 & 7 & 40 & 0.015 & $\begin{array}{l}50 \\
50\end{array}$ & $\begin{array}{l}6 \\
6\end{array}$ & $\begin{array}{l}6 \\
5\end{array}$ & $\begin{array}{l}4 \\
6\end{array}$ & $\begin{array}{c}7.5 \\
9\end{array}$ & $\begin{array}{l}9.3 \\
10\end{array}$ & $\begin{array}{l}3.0 \\
4.5\end{array}$ \\
\hline $\begin{array}{l}\text { Hardwick, } \\
\text { Vermont }\end{array}$ & 1,400 & 90 & 4 & 15 & 0.002 & 65 & 8 & 4 & 1 & 7 & 7.6 & 3.1 \\
\hline $\begin{array}{l}\text { Salmon River, } \\
\text { Connecticut }\end{array}$ & 2,000 & 120 & 8 & 17 & 0.002 & 45 & 9 & 6 & 2.5 & 6 & 4.0 & 2.0 \\
\hline $\begin{array}{l}\text { Grasse River, } \\
\text { New York }\end{array}$ & 8,000 & 375 & 10 & 21 & 0.0001 & 60 & 8 & 4 & 4 & 10 & 3.1 & 2.5 \\
\hline \multicolumn{13}{|c|}{$\begin{array}{l}E=\text { Existing } \\
S C=\text { Scheduled for construction } \\
C D=\text { Conceptual desian }\end{array}$} \\
\hline
\end{tabular}


Where HEC-RAS predicts water velocities in the ice jam toe region in excess of $5 \mathrm{ft} / \mathrm{s}$, the equivalent prototype ice jams are probably grounded. This observation is based on CRREL physical model tests of the Hardwick and Cazenovia Creek ICS, as well as the prototype Hardwick ICS, where grounded ice jam toe conditions occur.

In cases where the HEC-RAS results predict high under-ice water velocities in the mid-jam section ( $\geq 4 \mathrm{ft} / \mathrm{s}$ ) or no floodplain is available to bypass relief flow, ice jam stability is questionable and design confidence requires a more sophisticated modeling approach than HEC-RAS. It may be possible to retain ice under these conditions, but a physical model study will probably be needed to ensure the desired performance.

HEC-RAS is also useful for calculating the profile of the downstream jam with the reduced ice volume (i.e., evaluating downstream benefits). In this case, the ice volume held by the ICS reduces primarily the extent of downstream overbank flow by reducing ice volume in that jam. However, because the ICS normally is designed to hold ice at high discharge, the downstream jam should blow out below the design discharge. HEC-RAS stability analyses can help determine the discharge at which this occurs (e.g., Fig. 4).

Beyond about two river widths upstream of the ICS, the ice jam profile is essentially independent of the toe details. HEC-RAS analyses thus can provide the basis for determining real estate requirements for the project by defining the extent of over-bank flow caused by the ICS jam (Section 2.9). It is important to recognize, however, that the model parameters, especially those related to the ice, are estimates that include some level of uncertainty. This will propagate uncertainty into the estimates of over-bank flooding.

\subsection{Pier Design}

At this point, pier design is more experience-based than theoretical. Parameters of pier design include pier spacing, height, width, and shape, the most important being spacing and height. In existing structures, pier spacing ranges from 6 to $20 \mathrm{ft}$, with recent designs favoring a gap width of about $12 \mathrm{ft}$. The design intent is to maximize the spacing without sacrificing ice retention performance. A wider gap width reduces the number of piers and project cost and also minimizes potential for debris snagging and interference with recreational uses of the river.

The Cazenovia Creek ICS, which is designed to arrest and retain dynamic ice runs, calls for 5 -ft-diameter cylindrical piers with 12 -ft-wide gaps. The Salmon River ICS will have 2.5 -ft-wide rectangular piers with the same gap width. In 
both cases, the piers rise about $3 \mathrm{ft}$ above top of bank. The Hardwick ICS granite blocks have $45^{\circ}$ inclined-front faces and 14-ft gaps and rise about $1 \mathrm{ft}$ above bank height.

Some guidance is available to scale these designs to other locations. Experiments by Calkins and Ashton (1975) showed that, for surface concentrations greater than about 30 percent, moving ice will arch between piers when the ratio of the gap width, $\mathrm{G}$, to the average floe diameter, L, was less than about 4 . Lever et al. (1997) found that a sloped-block ICS arrested a dynamic ice run and held the resulting ice jam when $\mathrm{G} / \mathrm{L}$ was less than about 5-6. Typically, the average diameter of breakup ice floes is about 3-4 times ice thickness, T. If we suggest that $\mathrm{G} / \mathrm{L}$ be less than 5 and $\mathrm{L} / \mathrm{T} \sim 3$, then $\mathrm{G} / \mathrm{T}<15$ should give good ice arrest and holding performance. This is consistent with the performance of the slopedblock ICS, namely that $\mathrm{T} / \mathrm{G}>0.07$ allows the ICS to hold ice throughout an event (Lever and Gooch 2005, in review). At a given site, the ICS gap width thus can be set at about 15 times the minimum ice thickness that poses an ice jam threat under existing conditions.

Piers should be slightly higher than the local top-of-bank height to ensure that the ice doesn't easily overtop them during high discharge events. Model tests and field performance of the sloped-block ICS (Lever et al. 1997, Lever and Gooch in review) and model tests of a cylindrical-pier ICS (Lever and Gooch 2001) show that ice can rise several feet above the piers without releasing catastrophically over them. If the piers are above the top of bank, floodplain flow limits stage rise and permits the ICS to hold ice at high discharge.

A number of pier ICSs are designed so that ice floes ground upstream of the piers in addition to arching. As previously mentioned, it is advantageous to locate an ICS on a flat section of river so that immediately before breakup, a thick competent ice sheet exists upstream of the structure. The arriving breakup front pushes these semi-intact sheets and large floes against the piers, arresting the upstream ice run through a combination of grounding and arching.

Natural levees and trees lining the riverbank help contain the ice in the main channel. Lacking trees along the bank, some designs call for lines of posts, boulders, or large concrete weights to help contain the ice in the main channel. Lever et al. (2000) calculated ice forces on ice-retaining posts based on the maximum head differential between the main channel and the floodplain. Typically, the jam thickness and height increase rapidly immediately upstream of the ICS, creating a condition where stage on the floodplain may be greater than the adjacent water surface elevation near the piers. As a result, flow returning from the floodplain to the main channel may wash out ice pieces between the piers, causing partial jam failure. In the Cazenovia Creek design, Lever et al. (2000) 
solved this with the addition of a 300 -ft-long rock berm along the floodplain margin, extending $150 \mathrm{ft}$ above and below the piers. The crest of the berm is level with the pier tops, which are about $3 \mathrm{ft}$ above top of bank (Fig. 6).

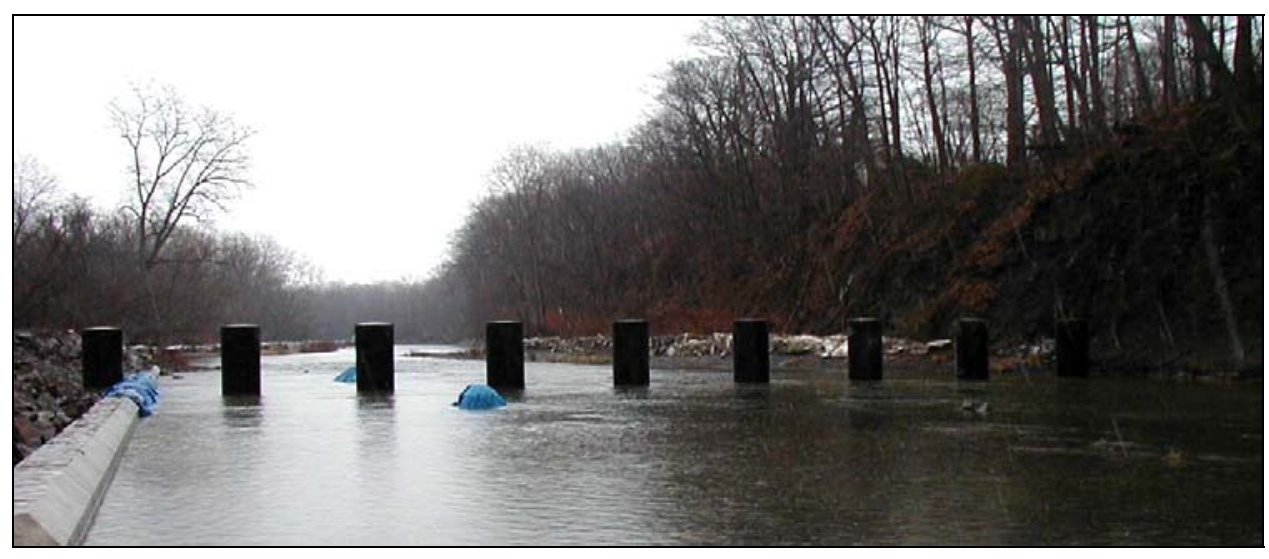

Figure 6. Cazenovia Creek ICS, January 2006, looking upstream. A concrete toe holds riprap along the right bank to prevent scour by floodplain flow returning to the main channel.

It was determined, as a result of physical model tests at CRREL, that actual pier shape is less important than pier spacing and height. In terms of performance, cylindrical piers proved comparable to rectangular piers with rounded noses of the same diameter. Vertical-faced piers were found to hold ice to higher discharge than piers with front faces inclined at $45^{\circ}$.

\subsection{Ice Forces on the Piers}

Ice forces on the piers can be determined through physical model experiments (Lever and Gooch 2001) or estimated based on bridge pier design guidance such as AASHTO (1998). The CRREL DEM (Daly and Hopkins 2001) also predicts ice forces on structures, as does the DynaRICE numerical model. Although a number of ice-loading scenarios are possible, maximum ice forces usually result from the initial impact of large floes against the piers (Fig. 7). Lower but more sustained ice loadings typically follow as additional ice accumulates upstream of the piers and the hydrostatic head builds. Once upstream stage exceeds bankfull depth and flow escapes onto the floodplain, the jam may ground to the bed, decreasing the ice loading on the piers.

Lever et al. (2000) analyzed moment and force data from the Cazenovia Creek ICS physical model tests and compared results to a maximum ice loading calculated using the AASHTO (1998) standards. Lever et al. assigned probabili- 
ties to moment and force data from some 20 lab experiments, obtaining a 0.001 chance of excedance force of 450 kips per pier. Through comparison of measured moment and force data they calculated an average moment arm of $4.4 \mathrm{ft}$ up from the river bed. The average ratio of transverse to downstream moments on the piers was found to be 0.45 . The authors then compared these results to design guidance from the AASHTO (1998) standards, assuming a maximum ice thickness of $2.0 \mathrm{ft}$, a floe diameter of $30 \mathrm{ft}$, and an effective ice strength of $220 \mathrm{psi}$. The resulting downstream force was calculated as 400 kips per pier, quite close to the value based on the model tests. However, the AASHTO standards pertain to the design of bridge piers and thus do not suggest a height to apply this force to calculate overturning moment for ICS piers. Also, the standards recommend application of a transverse force only $15 \%$ times the downstream force and are thus unconservative compared with the model results.

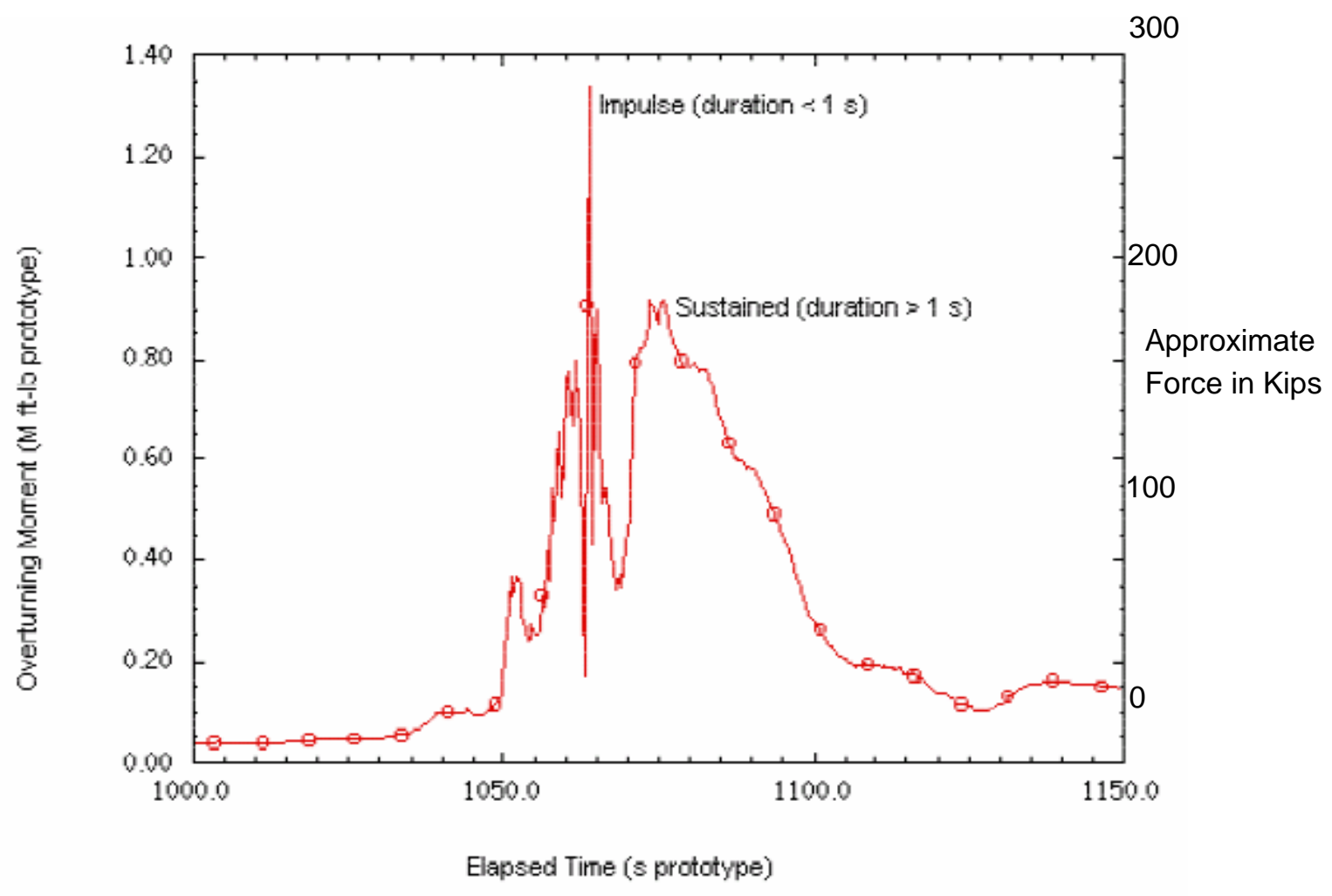

Figure 7. Measured moments on a pier, Cazenovia Creek physical model study. (From Lever et al. 2000.) 


\subsection{Bed and Bank Protection}

The bed and banks can experience extremely high shear stresses as a result of high water velocities and turbulence caused by an ice accumulation at the ICS. Bed and bank materials may also be disturbed by direct impact of gouging of ice floes as they accumulate at the ICS. Existing methods for calculating bed shear stress under an ice cover include the depth-slope product and drag formulas such as the Darcy Weisbach equation. Beltaos (2001) describes a practical approach for incorporating the effect of ice cover roughness into drag equations for calculating bed shear. More recent experiments (Hains and Zabilansky 2005) and field measurements of hydraulic scour beneath ice jams (Alcoa 2004) indicate that traditional bed shear calculation methods based on average water velocity and flow depth may be unconservative because they fail to account for the turbulent kinetic energy resulting from a rough ice cover. Because of these uncertainties, a conservative approach might be to calculate the bed-shear-based average underice depth and water velocity and roughness factors calculated from Beltaos (2001), then apply a factor of safety of at least three where thick ice accumulations and high turbulence are expected.

Areas around an ICS that typically experience high bed shear include the riverbed and banks near the piers, and the floodplain margins where bypass flow escapes and re-enters the main channel. The pier foundation design may call for a continuous concrete apron to resist overturning and sliding, which will also serve to prevent bed scour at the pier bases. Lacking a concrete apron, a riprap blanket may be needed around the piers bases. Stone bed and bank protection will also be needed upstream of the piers where the bottom of the ice accumulation is close to the bed or grounded, and downstream where flow jets out through the gaps between the piers. Where large moving ice floes are anticipated, to avoid rock movement, Sodhi et al. (1996) recommend a D100 stone size twice the maximum expected ice thickness for shallow slopes $(<1 \mathrm{~V}: 3 \mathrm{H})$ and three times the ice thickness for steeper slopes $(>1 \mathrm{~V}: 1.5 \mathrm{H})$.

\subsection{Extreme Events Failure Modes and Ice jam Meltout}

Any structure placed in a river will be subject to a wide range of natural conditions and, in some instances, the ICS may fail to retain ice. At the low end of the range, the ice will need to reach a minimum thickness before the average piece size is large enough to arch or ground at the piers. An early season ice release of thin ice through the structure is not of great concern as an ice run composed of small pieces is unlikely to form a serious jam at the ice jam problem area downstream of the ICS. Based on New England rivers, severe ice jams are uncommon for ice thicknesses less than about eight inches while severe ice jams 
are associated with pre-breakup ice thicknesses of $1 \mathrm{ft}$ or more. Lever and Gooch (2005, in review) discuss the relationship between ice floe thickness and the reliability of the Hardwick, Vermont, ICS since its construction in 1994.

In many regions, such as the northeastern United States, the peak annual discharge can occur at any time of the year and ice breakup may occur during the peak flow event. Where this is a possibility, the structure must be designed to retain ice during a worst-case flow event without catastrophic release occurring. Physical model tests or comparisons to similar existing ICS may be used to assess the structure's ice retention capability at the expected maximum flows.

Depending on the form of the extreme event hydrograph, it may be possible to demonstrate ice jam meltouts before the hydrograph peaks. This occurs as a result of the rapid heat exchange due to the high water discharge and the slightly above-freezing water temperatures typical of the breakup period. Lever et al. (2000) analyze progressive washout and melting during a hypothetical extreme discharge event on Cazenovia Creek, estimating the ice volume lost to melting per ${ }^{\circ} \mathrm{F}$ above freezing to be about $1 \%$ of the water discharge rate. The authors developed a maximum upstream water surface profile by superimposing a series of HEC-RAS simulations with progressively increasing discharge and decreasing ice volume.

The rapid melt rate resulting from high water discharge explains why observed jams often disappear very quickly. For instance, $33^{\circ} \mathrm{F}$ water, flowing at $10,000 \mathrm{cfs}$, will melt out a substantial jam of 10 million cubic $\mathrm{ft}^{*}$ in only 17 hours. Based on this, if the hydrograph takes a day or more to rise from the breakup level to the peak, then the accumulation may well melt in place rather than release at the ICS.

\subsection{Upstream Property Effects}

A breakup ICS is designed to hold ice upstream of a traditional problem location. A direct consequence of this ice-control benefit is that the retained jam is likely to increase the extent, height, or duration of high water upstream of the ICS site. It is extremely important to estimate these effects when assessing candidate sites and to minimize upstream flooding and to delineate real estate requirements such as flowage easements. The floodplain adjacent to the ICS and immediate upstream sections will potentially experience annual flooding and probably should be purchased outright for the project.

\footnotetext{
${ }^{*}$ Assuming a porosity of 0.4 , the jam will contain six million $\mathrm{ft}^{3}$ of solid ice.
} 
HEC-RAS can be an effective tool to estimate upstream effects of an ICS (Lever and Daly 2003). The downstream location of the jam can be set to the ICS location, and except for a few river widths closest to the structure, the model's requirements of steady, gradually varied, one-dimensional flow are generally met. Section 2.4 provides guidance on the use of HEC-RAS for ice jam modeling.

As mentioned, ICSs can be designed to hold ice at very high discharge during an extreme breakup event. The volume of ice retained will thus decrease during the event owing to melting and washouts. Cumulatively, these effects can significantly reduce the extent of high water and over-bank flooding upstream and thus play major roles in the delineation of real estate requirements for the project. Although some guidance is available (Lever and Daly 2003), sitespecific water temperatures immediately following breakup and model tests documenting the rate of ice washouts through the ICS provide the best data to quantify these effects.

\subsection{Environmental Impacts}

A major advantage of a pier ICS is its relatively small impact on the physical environment. Lacking a weir and utilizing a natural floodplain, the ICS causes minimal disruption of the open-water hydrology and hydraulics of the river. Over-bank flow, if it occurs, coincides with ice breakup and typically only for fairly severe events (large ice thickness, high discharge). For most rivers, it is thus limited to a day or so per severe event and thus may not occur annually (Lever and Gooch 2005).

Nislow and Lever (1997) documented relatively small ecological impacts and some small benefits during an initial assessment of the sloped-block ICS in Hardwick, Vermont. In particular, the piers and associated riprap increased the largestructure cover for a river section lacking this habitat.

Most importantly, the main function of an ICS, mitigation of downstream ice jam flooding, carries with it significant environmental benefits. By reducing the frequency, extent, or duration of flooding, an ICS can reduce the pollutants (e.g., fuel oil, household hazardous wastes, etc.) commonly spilled into rivers during ice jam events. 


\section{SUMMARY AND CONCLUSIONS}

This report outlines basic steps involved with the design of breakup ice control structures and Appendix A provides a checklist summarizing these steps. A range of breakup ICS types are described with a focus on the design of pier ICS with floodplain flow relief, as these structures are currently the most economical and reliable, with the least environmental impact. Design steps include characterization of the existing ice regime based on a review of historic ice events, collection of hydrometeorological data, and a field inspection of the river for past ice jam evidence. ICS site selection must consider local hydraulic and geomorphologic conditions, upstream effects, and potential benefits in terms of reducing the downstream ice jam problem. Available calculation and modeling methods are discussed with an emphasis on the use of the HEC-RAS model to evaluate important design parameters such as under-ice erosion and ice jam stability. Important aspects of pier design such as spacing and height are discussed along with methods for estimating ice forces on the piers. Calculation methods for bed and bank shear forces are outlined for use in the design of bed protection, and ICS failure modes are discussed. Background publications and more sophisticated ice-hydraulic models are referenced. Finally, a summary report on the recent performance of breakup ICS (Tuthill 2005) can be found at http://www.crrel.usace.army.mil/techpub/CRREL_Reports/reports/TN05-5.pdf. 


\section{REFERENCES}

Abdelnour, R. (2003) Proposal to retain ice on the upper Grasse River using a series of steel pipe booms. Submitted to Camp Dresser McKee by Fleet Technology, Inc. (http://www.fleetech.com/capabilities_coldregions booms.html).

Alcoa (2004) Addendum to the comprehensive characterization of the Lower Grasse River, Volume 1: Main Report, Grasse River Study Area, Massena, New York.

Beltaos, S. (1993) Numerical computation of river ice jams. Canadian Journal of Civil Engineering, Vol. 20, p. 88-99.

Beltaos, S. (2001) Hydraulic roughness of breakup ice jams. Journal of Hydraulic Engineering, Vol. 127, No. 8.

Calkins, D.J., and G.D. Ashton (1975) Arching of Fragmented Ice Covers. U.S. Army Cold Regions Research and Engineering Laboratory, Hanover, New Hampshire, Special Report 222.

Daly, S.F., and M.A. Hopkins (2001) Estimating forces on an ice control structure using DEM. In Proceedings, 11th Workshop on the Hydraulics of IceCovered Rivers, 14-16 May 2001. Published on CD-ROM by the Committee on River Ice Processes and the Environment, Canadian Geophysical Union, Hydrology Section, Ottawa, Canada.

Hains, D., and L. Zabilansky (2004) Laboratory tests of scour under ice: Data and preliminary results. U.S. Army Engineer Research and Development Center, Cold Regions Research and Engineering Laboratory, Hanover, New Hampshire, ERDC/CRREL Technical Report TR-04-9.

Lever, J.H., and S.F. Daly (2003) Upstream effects of Cazenovia Creek icecontrol structure. Journal of Cold Regions Engineering, ASCE, 17(1): 3-17.

Lever, J.H., and G. Gooch (1998) Model and field performance of a sloped block ice control structure. In Ice in Surface Waters (H.T. Shen, Ed.), Proceedings of the 14th International Symposium on Ice, Potsdam, New York, Vol. 2, p. $647-652$.

Lever, J.H., and G. Gooch (2001) Design of the Cazenovia Creek ice control structure. Journal of Cold Regions Engineering, ASCE, 15(2): 103-124.

Lever, J.H., and G. Gooch (2005) Performance of a sloped-block ice-control structure in Hardwick, Vermont. In Proceedings, 13th Workshop on the Hydraulics of Ice-Covered Rivers, Hanover, New Hampshire, 15-16 September 2005, p. 310-316. 
Lever, J.H., and G. Gooch (in review) Assessing the performance of a sloped block ice-control structure. Journal of Cold Regions Engineering, ASCE.

Lever, J.H., G. Gooch, A. Tuthill, and C. Clark (1997) Low-cost ice-control structure. Journal of Cold Regions Engineering, ASCE, 11(3): 198-220.

Lever, J.H., G. Gooch, and S.F. Daly (2000) Cazenovia Creek ice control structure. U.S. Army Engineer Research and Development Center, Cold Regions Research and Engineering Laboratory, Hanover, New Hampshire, ERDC/ CRREL Technical Report TR-00-14.

Morse, B., J. Francoeur, H. Delcourt, and M. Leclerc (in press) Ice control structures using piers, booms, and nets. Cold Regions Science and Technology.

Nislow, K.H., and J.H. Lever (1998) Assessing the ecological impact of an ice control structure. In Ice in Surface Waters (H.T. Shen, Ed.), Proceedings of the 14th International Symposium on Ice, Potsdam, New York, Vol. 2, p. 787-792.

Shen, H.T., J. Su, and L. Liu (2000) SPH simulation of river ice dynamics. Journal of Computational Physics, 165(2): 752-777.

Tuthill, A.M. (1995) Structural Ice Control, Review of Existing Methods. U.S. Army Cold Regions Research and Engineering Laboratory, Hanover, New Hampshire, Special Report 95-18.

Tuthill, A.M. (2005) Breakup ice control structures: Performance review. U.S. Army Engineer Research and Development Center, Cold Regions Research and Engineering Laboratory, Hanover, New Hampshire, ERDC/CRREL Technical Note TN-05-5.

Tuthill, A.M., J.L. Wuebben, S.F. Daly, and K.D. White (1996) Probability distributions for peak stage on rivers affected by ice jams. ASCE Journal of Cold Regions Engineering, Vol. 10, No. 1, p. 36-57.

Tuthill, A.M., L. Liu, and H.T. Shen (2005a) Breakup ice control structure with in-channel relief flow. In Proceedings, 13th Workshop on the Hydraulics of Ice-Covered Rivers, Hanover, New Hampshire, 15-16 September 2005.

Tuthill, A.M., G.E. Frankenstein, M. Kenney, and A. Mihm (2005b) Ice tree scar evidence of historic ice events on the Grasse River. In Proceedings, 13th Workshop on the Hydraulics of Ice-Covered Rivers, Hanover, New Hampshire, 15-16 September 2005.

U.S. Army (2000) HEC-RAS River Analysis System. Users Manual, Version 3.1.2, U.S. Army Corps of Engineers, Hydrologic Engineering Center, Davis, California. 
USACE (2002) Ice Engineering, EM 1110-2-1612. Department of the Army, U.S. Army Corps of Engineers, Washington, DC (http://www.usace.army.mil/ inet/usace-docs/eng-manuals/em1110-2-1612/toc.htm).

White, K.D. (1999) Hydraulic and physical properties of ice jams. U.S. Army Cold Regions Research and Engineering Laboratory, Hanover, New Hampshire, CRREL Report 99-11. 


\section{APPENDIX A. BREAKUP ICS DESIGN PROCEDURE}

1. Characterize existing ice regime and ice jam problem.

Research historical ice events.

Inspect study area for evidence of past ice action and jams.

Analyze hydrometeorological data related to ice breakup.

Calculate maximum pre-breakup ice thickness based on air temperature data.

Relate hydrograph data to nature of ice breakup severe ice events.

Construct ice-affected rating curve for project reach.

Estimate frequency and severity of past ice jam events.

Determine "worst-case" ice event for use in ICS design.

Identify probable ice source reach and estimate enroute ice losses.

Estimate maximum probable ice supply.

Obtain post-breakup water temperature data.

2. Select ICS location.

Seek site with favorable hydraulic conditions:

Can a stable ice accumulation exist upstream of piers for expected discharge range?

Will under-ice water velocities exceed the ice erosion threshold?

Will ice run from upstream impact a sheet ice cover upstream of piers or open water?

Consider channel morphology at the ICS, and upstream and downstream:

Does site provide overbank relief flow around jam in main channel?

Does upstream reach provide sufficient upstream ice storage?

Will ICS retain sufficient ice volume to alleviate downstream ice jam problem? 
To what degree will stage rise from the ICS affect upstream properties?

3. Model ice accumulations under existing conditions and with ICS alternatives.

Select modeling approach based on problem complexity, scale, uncertainty, and resources:

One-dimensional steady-state hydraulic equations with equilibrium ice jam theory

HEC-RAS 1-D, gradually varied flow model with wide jam ice routine (and similar)

DynaRICE 2-D, dynamic, ice-hydraulic model

CRREL discrete element model with ADH hydrodynamics

Physical hydraulic model with plastic or real ice

Calibrate model to existing-conditions "worst case" ice event.

Simulate ice accumulations for range of ICS site alternatives, considering the following:

Ice holding capacity of the piers

Ice accumulation stability

Under-ice erosion

Relief channel capacity

Upstream ice storage capacity

Upstream water level rise, (considering ice bleed-through and melting)

Effect of upstream ice retention on downstream ice jam problem

4. Structural Design

Pier spacing and height:

Select pier spacing based on existing designs such that ice accumulation arches or grounds upstream of piers.

Select pier height such that ice remains in main channel allowing water flow to escape to floodplain.

Ensure that relief flow channel remains ice-free. 
Natural levees, trees, boulders, piers, etc., to retain ice in main channel

Estimate ice forces and moments on piers based on the following:

AASHTO bridge design code

Existing ICS designs

CRREL DEM or DynaRICE numerical model force outputs

Measured data from physical ice-hydraulic models with instrumented piers

Estimate shear forces and design bed and bank protection based on the following:

Classic 1-D shear and drag equations and Beltaos (2001) to incorporate effect of ice cover roughness

Recognize added shear resulting from turbulence and apply a significant factor of safety.

Consider potential for direct impact by ice floes and size armor stone according to Sodhi et al. (1996).

Consider extreme events and possible failure modes:

Ice bleed-out and blowouts at piers

Progressive ice accumulation meltout scenarios as flow increases (Lever 2000)

With regard to potential failure modes, err on the conservative side:

Ensure that ICS project does not introduce a greater hazard than the original problem that you are trying to solve.

5. Upstream Real Estate Requirements

Estimate initial ice jam volume: ice supply, transport losses.

Estimate ice losses from melting and minor washouts through the ICS.

Calibrate HEC-RAS or equivalent numerical model.

Compare worst-case upstream flooding with existing flooding or 100-year floodplain definition. 


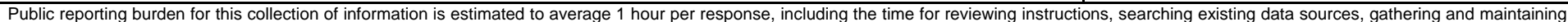

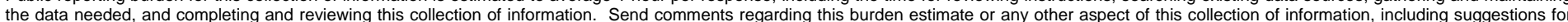

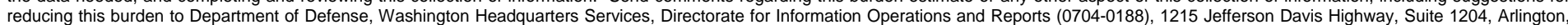

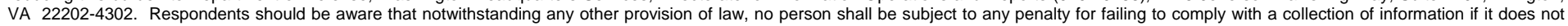
display a currently valid OMB control number. PLEASE DO NOT RETURN YOUR FORM TO THE ABOVE ADDRESS.

\begin{tabular}{l|l}
$\begin{array}{l}\text { 1. REPORT DATE (DD-MM-YYYY) } \\
\text { March } 2006\end{array}$ & $\begin{array}{l}\text { 2. REPORT TYPE } \\
\text { Technical Report }\end{array}$ \\
\hline
\end{tabular}

4. TITLE AND SUBTITLE

Design of Breakup Ice Control Structures

3. DATES COVERED (From - To)

5a. CONTRACT NUMBER

5b. GRANT NUMBER

5c. PROGRAM ELEMENT NUMBER

6. AUTHOR(S)

Andrew M. Tuthill and James H. Lever

5d. PROJECT NUMBER

5e. TASK NUMBER

5f. WORK UNIT NUMBER

7. PERFORMING ORGANIZATION NAME(S) AND ADDRESS(ES)

8. PERFORMING ORGANIZATION REPORT NUMBER

U.S. Army Engineer Research and Development Center

Cold Regions Research and Engineering Laboratory

ERDC/CRREL TR-06-7

72 Lyme Road

Hanover, New Hampshire 03755-1290

9. SPONSORING I MONITORING AGENCY NAME(S) AND ADDRESS(ES)

U.S. Army Corps of Engineers

Washington, DC 20314-1000

10. SPONSOR/MONITOR'S ACRONYM(S)

USACE

11. SPONSOR/MONITOR'S REPORT NUMBER(S)

\section{DISTRIBUTION / AVAILABILITY STATEMENT}

Approved for public release; distribution is unlimited.

Available from NTIS, Springfield, Virginia 22161.

13. SUPPLEMENTARY NOTES

\section{ABSTRACT}

The primary purpose of a breakup ice control structure (ICS) is to retain a breakup ice run upstream of a traditional ice jam problem area and thereby mitigate ice-jam flooding. By controlling ice-jam location, breakup ICSs also can prevent ice-related scour associated with dam removals or contaminated sediment remediation projects. This report briefly describes basic ICS types, purposes, and advantages and disadvantages, and provides engineering design guidance for their use. The use of numerical and physical models to design these structures is illustrated through case studies. The report includes a checklist to help designers compile the necessary input data and to conduct the analyses needed to ensure successful designs.

\section{SUBJECT TERMS}

Breakup ice control structure Design guidance for ice control structures 16. SECURITY CLASSIFICATION OF: a. REPORT $\mathrm{U}$ b. ABSTRACT $\mathrm{U}$ c. THIS PAGE U

Ice hydraulic modeling Ice jam flood control Ice retention piers

THIS PAGE
U

\begin{tabular}{|c|c|} 
17. LIMITATION & $\begin{array}{l}\text { 18. NUMBER } \\
\text { OF ABSTRACT }\end{array}$ \\
OF PAGES \\
\end{tabular}

19a. NAME OF RESPONSIBLE PERSON

19b. TELEPHONE NUMBER (include area code) 